\title{
The Influence of Time Budget Pressure and Dysfunctional Behavior to Audit Quality at Bawasda in Gorontalo Province
}

\author{
Rio Monoarfa and Hais Dama \\ Gorontalo State University \\ Email:rio_mono@yahoo.com
}

\begin{abstract}
Abstract: This Study is aimed to find out: (1) the influence of time budget pressure and dysfunctional behavior to audit quality simultaneously, and (2) the influence of time budget pressure and dysfunctional behavior to audit quality partially. Population in this study are all auditors of Offices of BAWASDA in Gorontalo Province. The study has used a census method, whereas its data collection techniques were done through spreading and filling questionnaires and direct interviews. Hypotheses in this study have been tested using a path analysis. The results of the study have shown that time budget pressure and dysfunctional behavior have simultaneously and partially affected the audit quality.
\end{abstract}

Keywords: time budget pressure, dysfunctional behavior, audit quality.

\section{INTRODUCTION}

The public sector has been undergoing major changes since the reformation era. Two fundamental changes in public sector happen on governance system and on local and national financial system (Mardiasmo, 2002). In governance system, the changes happen is regional autonomy and vast and accountable decentralization whereas changes on national and local financial system happen in budget reformation, accounting reformation, and financing reformation, and local financial management.

Reformation on the audit system is needed to ensure public accountability by the government as state wealth is the people's wealth. The community as principal has a strong interest in public budget managed by the government. However, as the public is unable to evaluate the financial statement of the government, hence, the professional party often called as auditor, either internal or external, is needed in evaluating the government financial statement. The audit report is the quality assurance for the principal (Mardiasmo, 2002). According to the Committee on Basic Accounting Concept, the role of audit is very crucial in ensuring the need of the accounting information users by providing insurance in form of value-added information and communicating it to the users, (Kalau,2013).

Planning and budgeting in the public sector are closely related to political aspect (Mardiasmo,2002) including the availability of budget for audit. The reduction of the budget for audit will result in the reduction of audit time (budget time). Therefore, control by audit management in the utilization of budget for audit time to ensure efficiency and effectivity of budget for an expected quality audit.

One of the keys to operational and management control in audit deployment is time budget (Soobaroyen and Chengabroyan, 2005). Auditing is an activity to intensify the workers, hence, best ways to cost control are through time management, and budget pressure which are a normal description of auditor control system. The control system implemented often resulted in less than expected impact on auditor itself as found in the research carried out in several Public Accounting Offices in the USA, which identify types 
of dysfunctional behaviors such as premature sign off and underreporting of chargeable time and perception of those behaviors, especially related to the audit time and overall management system (Otley and Pierce, 1996). Pressure and the constraint of time budget also resulted in a less expected impact on the reduction of audit quality (Coram et al., 2001; Otley and Pierce, 1996; Cook and Kelley, 1991).

Based on previous studies, the dysfunctional behaviors (such as premature sign-off and underreporting of chargeable time) are rooted on a budget as management control toll and staff evaluation. In general, auditors consider performance evaluation and carrier promotion in audit firm are closely related with the ability to accomplish audit tasks within the budget and time frame. At the same time, they also expected to fulfill all the tasks and audit procedure as the basis to enable them to form professional opinion according to the available standard and audit guideline. This is the basis of conflict and source of dilemma within the auditor themselves to accomplish audit task according to the budget time provided while at the same time upholding the high professional standard that they must obey (Soobaroyen and Chengabroyan, 2005).

This conflict and dilemma within an auditor are very reasonable due to the intention of the audit firm to reduce the budget time in order to be the best in budget time achievement (Kelley and Seiler, 1982).

This criterion puts the pressure for the auditor to fulfill the time budget pressure. This pressure often causes individual stress due to the imbalance of task and time allocated for that task against the professional ethics through attitude, intention, attention, and audit behavior (DeZoort,1 998; Kelley, Margheim, and Pattison, 1999). This negative influence often appears through negative behaviors such as premature sign-off and underreporting of chargeable time (Soobaroyen and Chengabroyan, 2005; Otley and Bernard,1996; Azad, 1994).

Behavior and actions that reduce auditor efforts and professional skepticism and professional judgment can lead to reduced Audit Quality, ie lower quality audits. Auditors perceive the pressure from the time budget set for their assignments to sign audit results before the audit steps are completed, receive doubtful and/or weak explanations from the client, and/or not report the time spent on assignments. This means that auditors do not maintain skepticism or make professional judgments and therefore audits that are conducted are less qualified (Broberg et al., 2017). The results of the study by Umar et al., 2017 show that Time Budget Pressure has a positive influence on Dysfunctional Audit Behavior. The implication of this research is that public accountants must manage the budget correctly so that pressures such as time budget can be reduced. Auditors always face the complexity of tasks in their work when pressures such as time budgets often occur in the audit process. The employment relationship model explains that pressure can reduce auditor performance so that it has the potential to make auditors behave dysfunctional. That pressure can make auditors take an instant way to complete an audit program such as changing audit procedures, ignoring audit procedures, early signs and underreporting time. Pressure can reduce audit quality so that, when auditors behave dysfunctional, their ability to detect fraud in the client's financial statements will decrease, (Umar et al., 2017).

Svanstrom, (2016) in his research examined the relationship between time pressure, training activities and the behavior of dysfunctional auditors in small audit firms. Based on a survey response from 235 certified auditors working in small audit companies in Sweden, the analysis shows that perceived time pressure is positively related to 
dysfunctional auditor behavior. These findings suggest that audit quality is at risk when auditors experience high time pressure.

Audit quality is often defined as probability of an auditor to determine and report misuse that happened in an accounting system of a client. Probability of finding abuse depends on the technical capacity of the auditor such as experience, professionalism, and audit structure of that company. Probability of auditor to report misuse within an accounting system of a client depends on the independency of that auditor (De Angelo, 1981). Carcello et al., (1992) proposed several factors such as the experience of audit team and firm with the client, industry expertise, responsiveness, and obedience toward GAAS as factors influencing the quality of the produced audit. Audit quality is also related to other factors such as gender, position, experience, number of clients, size of local offices and audit companies, (Broberg et al, 2017).

Recent development in auditing shows a signal of dissatisfaction toward the audit quality. Various critics have created needs and encouragement for the public accountant profession to increase the quality of their audit. Similar condition also happens in government sector which performance considered as of low quality (Pontas, 2004).

Local Audit Agency/Badan Pengawasan Daerah (BAWASDA) in each province and district/city, especially in Gorontalo province as one of the Government Internal Control Agency (APIP) as the research object is expected to become an independent and professional audit institution. Based on the Presidential Decree No. 74 of 2001 on Monitoring of the Regional Governance Implementation, Degree of Minister of Home affair and Regional Autonomy No. 17 of 2001 on Delegation of Functional Monitoring of the Implementation of Local Governance to Governor, Decree of the Minister of State apparatus Empowerment No. KEP/49/M.PAN/4/2005 on National Monitoring Policy of the Internal Government Monitoring Apparatus, and Annual Monitoring Work Program of the Central Government Implementation in 2005 and description of vision and mission on BAWASDA insisted that the role and function of the local monitoring agency encompasses but not limited to conducting monitoring of the local finance which consists of the compilation and implementation of the local budget and expenditure, budget and expenditure of the state-owned companies, conducting performance monitoring, obedience monitoring, monitoring for certain purposes, and follow up of the monitoring.

Gorontalo Province Inspectorate is a Technical Institution within the scope of Gorontalo Provincial Government formed based on Regional Regulation Number 13 of 2013 and Gorontalo Governor's Regulation Number 2014, is an implementing element of the regional government that is responsible to the Governor in the administration of Gorontalo Provincial government in the field of supervision. Before becoming the Gorontalo Province Inspectorate in 2007 earlier in 2002 the nomenclature was the Gorontalo Province Supervisory Agency which was formed based on Regional Regulation No. 15 of 2002. In accordance with the Gorontalo Governor's Regulation Number 59 of 2016, Gorontalo Province Inspectorate has Main Tasks to Assist the Governor in fostering and supervising the implementation government affairs which are the regional authority and co-administration duties to assist the Governor in administering the government. And has functions, among others, carrying out internal supervision of performance and finance through audits, reviews, evaluations, monitoring and other supervisory activities.

Based on the description above, it is clear that basically auditor, either internal or external auditor, those who work within private and public agencies will experience pressure due to the time budget against the demand to accomplish audit tasks and within 
the demand of their professionalism as auditors and thus, can influence the quality of the audit. Therefore, this study will be focused on "the influence of time budget pressure and dysfunctional behaviors toward the quality of the audit".

\section{METHODS}

This study is conducted to gather information on the influence of time budget pressure and dysfunctional behaviors on the quality of the audit, a case study in the office of Local Audit Agency (BAWASDA) in Gorontalo Province. According to Uma Sekaran (2003:117): The research design, which involves a series of rational decision-making choices. The research design of this study according to Uma Sekaran (2003: 118) is described as follow:

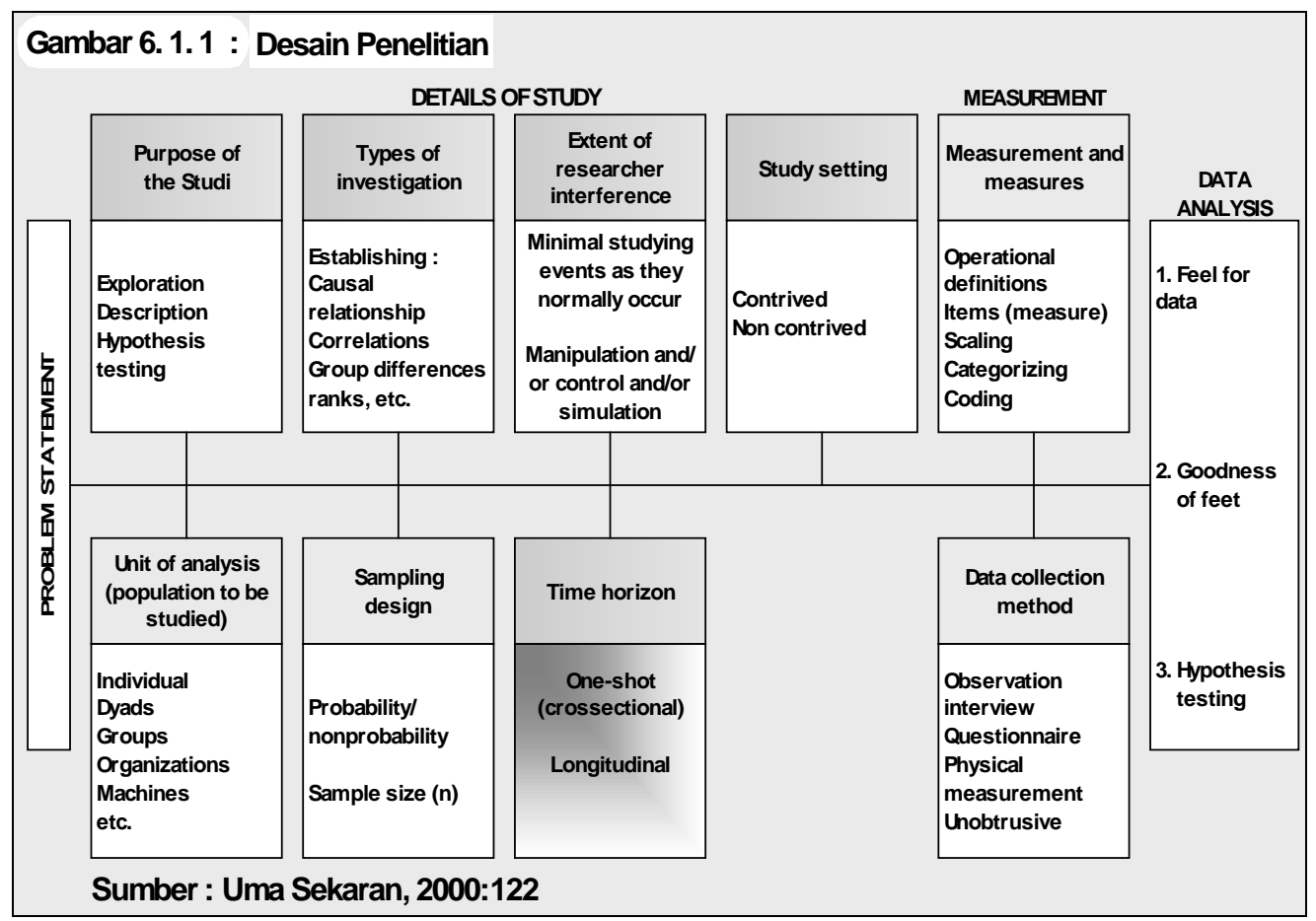

Figure 1. Research Design

The objective of this study is to test the hypothesis. The hypothesis in this study is developed based on the concept to determine the correlation between the identified variables through a clear conceptual framework. This research method is surveyed to obtain facts from the current phenomena and to investigate factual reasons (Nazir, 2003: 56). This type of research is a descriptive-analytical research. According to Nazir (2003: 89), descriptive analytical research is a study to find facts with appropriate interpretation and analytical is a study to test the hypothesis and comprehensively interpret those hypotheses into various correlations. Data collection in the field uses census method, that is all population is treated with the questionnaire to collect the data.

To ensure whether there is an influence of time budget pressure and dysfunctional behaviors on the quality of audit in BAWASDA of Gorontalo province, the hypothesis is tested through pathway analysis by previously conversing the ordinal scale into internal scale through successive interval method. The pathway analysis is used as this type of 
analysis is able to reveal the correlational or causality patterns among variables within the research.

\section{LITERATURE REVIEW}

Time Budget Pressure. Time Budget is a crucial thing to be considered. Within a normal circumstance, estimation of time allocated for specific tasks in an audit has to be provided as the basis to obtain an estimation of audit cost, to allocate tasks per personnel and to evaluate the performance of an auditor staff. If the time allocation for the task is insufficient, then the auditor may compensate with working fast and only accomplishing crucial tasks, hence, may result in ineffective performance. In other cases, the auditor may fail to find the misuse proof for an important audit (Waggoner, et al, 1991).

Time insufficiency provided will cause pressure for auditor and will have an impact on the accomplishment of the audit tasks. According to Dezoort (1998) who cited from the psychological literature, he described:

"It is generally thought that "under time pressure, subject tend to work more quickly, but performance accuracy declines"

Time budget pressure is a form of pressure resulted from the resource allocation constraint in order to accomplish a task, as DeZoort, (1998) wrote:

Time budget pressure is a relatively chronic, pervasive form of pressure that arises from the limitation on the resources allocable to perform tasks.

Further, DeZoort, (1998) described that resource is limited due to various reasons, including benefit capacity consideration, personnel limitation, and fee constraint. The empirical literature stated, either for internal or external auditor, time budget often limited and become an obstacle to ensure a quality audit.

Time budget pressure is one of the dimensions of the time pressure, while the other dimension in this time pressure is time deadline pressure that is a pressure from a due date or a target time for an auditor to accomplish his task. In auditing, deadline pressure comes from the audit firm, client or the third party such as the regulator. Research conducted by Kelley et al, (1999) which compare between time budget pressure and time deadline pressure, showed that senior auditor and staff auditor agree that time budget pressure has the stronger influence on the decrease of audit quality in general and on the lack of auditor working satisfaction.

Initially, accounting research on auditor taxation emphasizes the positive influence of time pressure. Of several kinds of literature, the benefit of time pressure is the increase of focus on tasks and relevant information; lack of focus on irrelevant tasks and information; an increase of motivation to improve work efficiency. Regardless, when time pressure becomes higher and surpasses the doable level, time pressure can yield the negative result (Kelley and Margheim, 1990; Glover, 1997; DeZoort, 1998; Soobaroyen and Chengabroyan, 2005). According to Edland and Svenson, (1993, 37-38) in DeZoort,(1998), they wrote that:

"Individuals under increasingly severe time pressure may first try to increase their processing speed. As time pressure increase, increasing speed becomes less feasible and individuals begin to filter the information they process". 
This statement is then called an inverted-U relationship. Psychological literature also stated that it is common that under the time pressure, the subject tends to work faster but with reduced accuracy. The correlation in inverted-U theory as the impact of pressure is described by Yerkes and Dodson, (1908) in Coram, et al, (2001):

"The inverted- $U$ theory proposes that there is a curvilinear relation between the amount of pressure and performance quality"

This theory is also proven by Kelley and Margheim, (1990) and Soobaroyen and Chengabroyan, 2005 which tested the correlation between time budget pressure and dysfunctional behavior, where their result was statistically significant to support the inverted-U theory.

The next researches have started to highlight the negative influence of time budget pressure. Most of these studies indicated that time pressure can encourage dysfunctional behavior such as premature sign-off and underreporting of chargeable time.

Time budget pressure which has an impact on the quality of the audit has been subject of studies conducted for the last 25 years in the USA, Ireland, New Zealand, and the United Kingdom. Several studies from these countries specifically identified types of dysfunctional behaviors such as, premature sign-off and underreporting chargeable time which give an impression that these behaviors are strongly related to control system in general and audit time budget in specific (Otley and Pierce, 1996).

Umar et al., (2017) explained based on some literature that time budget pressure is a time constraint that arises or may arise from limited resources (time) allocated for the implementation of audit tasks. This constraint can put pressure on the auditor because of the time is given by the public accounting firm to complete the audit task, and this has some impact on the quality reduction of decisions made by the auditor. The auditor can respond to pressure in two ways; whether in functional behavior or dysfunctional behavior. Auditors who behave functionally tend to provide extra energy to complete tasks and charge audit fees for performance. However, if the auditor behaves dysfunctional, audit quality will decrease both directly and indirectly. The dysfunctional behavior carried out by the auditor is like reducing or replacing some audit procedures and collecting ineffective audit evidence. Some researchers conducted to examine the relationship between time budget pressure on audit quality and unreported time. If time budget is difficult to achieve, dysfunctional audit behavior will increase.

The result of a study conducted by The Commission on Auditors Responsibilities, (1978) in Soobaroyen and Chengabroyan, (2005) recorded that time pressure as one of the auditor concern in accomplishing their responsibility. It was found that $60 \%$ of the respondents admitted that they do a premature sign-off due to time pressure. These studies indicated that the reduction of audit quality is due to time budget pressure, as cited in Soobaroyen and Chengabroyan, (2005):

"A tension between cost and quality and one factor that has been suspected of causing

a reduction in audit quality is the time budget pressure experienced by the auditors "

This result is also backed up by the result of Kelley and Margheim (1990) study which showed that $31 \%$ of senior auditor experienced time budget pressure and $41 \%$ of staff auditor is also reported to experience time budget pressure. They believe that time budget pressure may be the cause of the reduction of audit quality. 
Similar to the study conducted by Margheim and Pany (1986) in Soobaroyen and Chengabroyan, (2005), they stated that:

"Tight budgets often lead to auditors omitting parts of the audit program and thus to lower audit quality".

According to Coram (2001) in Soobaroyen and Chengabroyan, (2005) which stated that: "The level of time budget pressure impacts on the propensity to commit reduced audit quality ".

Cook and Kelley (1991) supported the notion above by stating that:

"Reduced audit quality has been found to be the less common result of meeting tight time budget"

Cause and consequence of dysfunctional behavior in the audit. In the literature, management control is reported by proof of dysfunctional behaviors as a response of the implementation of the procedure of the management control itself (Otley and Pierce, 1996). This is also supported by Soobaroyan and Chengabroyan, (2005) which stated that:

"Studies carried out within audit firm in the USA, UK, Ireland, New Zealand have identified specific types of auditor's dysfunctional behavior (such as under-reporting of chargeable time and premature sign-off) and suggested that this behavior was strongly related to the control system in general and to audit time budget in particular"

According to Donnelly, et al., (2003) Dysfunctional Behavior can influence the audit profession by reducing the quality of the audit as follow:

"Dysfunctional behavior and staff turnover are associated with decreased audit quality. Dysfunctional behavior such as premature sign-off, gathering of insufficient evidence, altering or replacing audit procedures, and underreporting of time have a negative effect on the auditing profession".

Similarly, Ponemon (2003) also wrote:

"The management control structure of a firm might inadvertently contribute to certain dysfunctional behaviors such as accepting and attempting to attain an unrealistic budget standard by distorting productivity measure, slacking off on work, or underreporting time".

DeZoort, (1998) explained that dysfunctional behavior is the result of the time budget pressure, in which he wrote:

"Evidence suggested that the demands of time pressure can diminish positive attitudes, intention, and behavior related to audit work. These negative effects include, for example, premature sign-off on procedures, underreporting time, feeling of failure, burnout, job dissatisfaction, and undesired turnover ".

Azad, (1994) stated:

"The effect of internal audit dysfunctional behaviors resulting from time budget pressure in audit quality is a significant problem".

Auditors perceive the pressure from the time budget set for their assignments to sign audit results before the audit steps are completed, receive doubtful and/or weak explanations from the client, and/or not report the time spent on assignments. This means that auditors do not maintain skepticism or make professional judgments and therefore audits that are conducted are less qualified (Broberg et al., 2017). Pressure can reduce auditor performance so that it has the potential to make auditors behave dysfunctionally. That pressure can make auditors take an instant way to complete an audit program such as changing audit procedures, ignoring audit procedures, early signs and underreporting time. 
Pressure can reduce audit quality so that, when auditors behave dysfunctionally, their ability to detect fraud in the client's financial statements will decrease, (Umar et al, 2017).

From these statements, it can be concluded that dysfunctional behaviors is strongly related with time budget pressure and has impact on the quality of audit. Literature on dysfunctional behaviors have largely discussed premature sign-off and underreporting of chargeable time as these behaviors are often happen and closely related to time budget pressure (Azad, 1994; Otley and Pierce, 1996; Soobaroyan and Chengabroyan, 2005). Nehme et al, 2017 in his study analyzed dysfunctional behavior (DB) through two proxies of dysfunctional behavior namely premature sign-off and underreporting of chargeable time. The results show that the auditor understands that dysfunctional behavior is carried out by the majority of auditors. Dysfunctional behavior is done intentionally.

Premature Sign-off. Premature sign-off as one of the dysfunctional behaviors according to Otley and Pierce, (1996) is the stoppage of audit steps which supposed to be accomplished and can threaten the quality of the audit. They wrote:

"Premature sign-off is the signing off of audit step as having been completed without carrying out the work or noting the omission. Since this type of behavior directly undermines the auditor's control system, it constitutes an immediate and serious threat to the quality of the audit.

Raghunathan (1991) wrote down:

"A commonly quoted outcome of the time and budget pressures is premature sign-offaudit personnel signing-off on audit program steps before completing one or more of the required audit procedures".

A similar view is also stated by Shapeero et al., (2003), as follow:

"A premature audit sign-off occurs when an auditor documents the completion of a required procedure that is not covered by other audit procedures, without performing the work or noting the omission of the procedure ".

From these views, it can be concluded that premature sign-off is an auditor activity to sign off early from audit procedure steps which can influence the audit quality. The Commission on Auditors' Responsibilities Report (1978) identified premature sign-off as the most critical issue found in the study and described evidence that budget pressure as the main factor that causes this behavior (Otley and Pierce, 1996).

A survey conducted by Rhode, (1978) on members of AICPA auditors and including the national, regional, and local auditors showed that almost $58 \%$ of them must take premature sign-off and 34\% of the respondents considered this action as the result of time budget pressure (Ragunathan, 1991). Otley dan Pierce, (1996) found that only $40 \%$ of the respondents who did not premature sign-off. Whereas, a study by Soobaroyan and Chengabroyan, (2005) found that $25 \%$ of the respondents agree or strongly agree that they have signed off on several audit steps in the accomplishment of their tasks as auditors.

Premature sign off has a direct impact on the quality of audit and is an offense toward their professional standard as auditors, as Shapeero et al, (2003) stated:

"Premature sign off directly affect audit quality and violate professional standards".

The impact of premature sign-off is reasonable as the failure of the audit is assessed based on the failure to implement all audit procedure, as concluded by Graham (1985) as cited in Shapeero et al, (2003) where he stated that: 
"Audit failure was often due to the omission of important audit procedures rather than procedures not being applied to a sufficient number of items. In turn, these audit failure not only significantly increase the litigation costs of CPA firms but may also hinder their ability to retain experienced personnel ".

Similarly, Azad (1994) described that the quality of audit is threaten when auditor does not implement several audit procedure:

"As for quality, the audit programs, while providing for specific procedures to be performed, are generally regarded as the minimum standard of performance to achieve audit quality. Thus, if some of the audit procedures are not performed and/or audit programs are overruled, audit quality may be sacrificed ".

Under-Reporting of Chargeable Time. Usage of chargeable time report is useful to charge the client, regulation of time budget is in accordance with the deployments, and evaluation of auditor performance. The ability of an audit institution to successfully implement their function depending on the accuracy of the time conducted by the auditor. However, previous studies have revealed that most accountants/auditors pay attention to the underreporting of their chargeable time (Shapeero et al, 2003).

Underreporting of chargeable time is a dysfunctional behavior that threatens the accountability of the audit process. According to Soobaroyan and Chengabroyan, (2005), Underreporting of chargeable time happens when auditor accomplishes their workload in their own time and often motivated to avoid or minimize the budget :

"Another specific dysfunctional behavior that poses a direct threat to the reliability of an audit process is underreporting of chargeable time. This occurs when auditors complete chargeable work on their own time and are usually motivated by a desire to avoid or minimize budget over-runs.

Further, Soobaroyan and Chengabroyan, (2005), stated that basically underreporting of chargeable time is indirectly threaten the audit quality, however, it may bring undesirable impact in the future. They wrote:

"Although this type of behavior (underreporting of chargeable time) does not pose an immediate threat to audit quality, it may lead to undesirable consequences such as inaccurate staff evaluation, lost revenue for the firm, unrealistic future budget and audit quality reduction behavior on future audits.

Similarly, Lightener, 1983, stated that underreporting of chargeable time is a side effect of time budget pressure and indirectly influence the quality of the work, however, it may lead to the error of other more serious time budget usage which influences the quality of the work. As underreporting often cause disruption of actual cost and hide the need to revise time budget. Lightner wrote:

"Underreporting of chargeable time is an undesirable side effect of many CPA firms' increasing emphasis on time budget... .Underreporting, however, doesn't directly affect job quality. However, underreporting can lead to the other more serious forms of time budget misuse that do affect the quality of work. Because it distorts actual and budget comparisons and obscures the need for time budget revision"

The evidence of underreporting of chargeable time has been widely discussed in several studies such as, Kelley and Seiler, (1982) who reported that 33\% survey conducted on the senior auditors acknowledge that they sometimes did an underreporting of 
chargeable time as a response to the budget pressure. Otley and Pierce,(1996) reported that $54 \%$ of the Irish senior auditors did a $10.9 \%$ cut on their chargeable time whereas Kelley and Margheim, (1990) estimated that staff auditors in the US did an underreporting of chargeable time by $3.2 \%$. In addition, Soobaroyan and Chengabroyan, (2005), showed that $77 \%$ of the respondents agree or strongly agree that auditors often work from home and did not report that working time when confronted with the time budget and $73 \%$ of the respondents believed that they have consciously did an underreporting of chargeable time (from sometimes too often).

The approaches on underreporting of chargeable time conducted by several researchers were based on several kinds of literature. Lightner et al, 1983 focused on underreporting of chargeable time in: (a) The frequency and extent of underreporting; (b) Accountants' perception of their ability to underreport without repercussions; (c) Accountants' ability to meet budgets if 100 percent of the chargeable time is reported; (d) Accountants' personal beliefs on the ethics of underreporting; (e) The effects of superiors' requests to underreport; (f) The perceived rewards of underreporting.

Approach conducted by Otley and Pierce (1996) was only focused on one indicator, the happening of "understate chargeable time". Whereas, Ponemon, (1992) measured the underreporting of chargeable time through the differences between self-reported completion time and actual (observed) completion time.

Soobaroyan and Chengabroyan (2005) focused their approach on: (1) implementation of audit tasks as homework and do not charge it into chargeable time, and (2) actual underreporting of chargeable time consciously on the level of auditor.

\section{RESULTS AND DISCUSSION}

Analysis on the respondents' responses is carried out by compiling a response table on items within the questionnaire based on variable, dimension, and indicator of the respondents' responses toward time budget pressure, dysfunctional behaviors, and audit quality. Based on this table, respondent's responses toward those three things will be described.

1) Time Budget Pressure. Time Budget Pressure felt by the auditors as respondents in this study is generally tight and fulfilled. This is shown by the proportion of the respondents' responses who gave score by $31.41 \%$ and who gave score 4 was $25.64 \%$.

Table 1. summary of respondents score on time budget pressure indicators

\begin{tabular}{|c|c|c|c|c|c|c|}
\hline Time Budget Pressure indicator & Score-5 & Score -4 & Score -3 & Score -2 & Score -1 & $\begin{array}{l}\text { Total } \\
\text { score }\end{array}$ \\
\hline Time budget pressure of the work in & 19 & 9 & 4 & 15 & 5 & \\
\hline the last year & $36,5 \%$ & $17,31 \%$ & $7,69 \%$ & $28,85 \%$ & $9,62 \%$ & 178 \\
\hline Success in meeting the budget time & $\begin{array}{c}16 \\
30,77 \%\end{array}$ & $\begin{array}{c}13 \\
25 \%\end{array}$ & $\begin{array}{c}14 \\
26,92 \%\end{array}$ & $\begin{array}{c}4 \\
7,69 \%\end{array}$ & $\begin{array}{c}5 \\
9,62 \%\end{array}$ & 187 \\
\hline Attainment of the time budget when & 14 & 18 & 12 & 2 & 6 & \\
\hline $\begin{array}{l}\text { Under Reporting of chargeable time } \\
\text { is not taken }\end{array}$ & $26,92 \%$ & $34,62 \%$ & $23,08 \%$ & $3,85 \%$ & $11,54 \%$ & 188 \\
\hline Accumulation & $\begin{array}{c}49 \\
31,41 \% \\
\end{array}$ & $\begin{array}{c}\mathbf{4 0} \\
25,64 \% \\
\end{array}$ & $\begin{array}{c}\mathbf{0} \\
19,23 \% \\
\end{array}$ & $\begin{array}{c}21 \\
13,46 \% \\
\end{array}$ & $\begin{array}{c}\mathbf{1 6} \\
10,26 \% \\
\end{array}$ & 553 \\
\hline
\end{tabular}

Source: processed research data 
Table 1 above shows that in general for the last year, $38.47 \%$ of the auditors felt that the time budget for the last year was very tight, which in practice was unattainable, and impossible to be attained. Nevertheless, $36.5 \%$ of the respondents felt under pressure to achieve the budget time. For the indicator of successful in meeting the budget time, 9 respondents or $17.31 \%$ stated that they never or rarely met the budget time. Nevertheless, $30.77 \%$ of the respondents believe that time budget is almost always met. Further, level of time budget attainment when underreporting of chargeable time was not conducted, $15.39 \%$ stated that it will never or rarely be achieved, however, $26.92 \%$ of the respondents stated that it is almost always be achieved.

\section{2) Dysfunctional behavior}

a) Premature sign off. Proportion of auditors as respondents in this study who committed premature sign-off as dysfunctional behavior in this study is almost never, this is evident from the accumulation of respondents who gave score 5 by $45.80 \%$ and those who gave score 4 was $24.83 \%$.

Table 2. Summary of respondents' score on premature sign-off indicators

\begin{tabular}{|c|c|c|c|c|c|c|}
\hline Indikator Premature Sign Off & Skor-5 & Skor-4 & Skor-3 & Skor-2 & Skor-1 & $\begin{array}{c}\text { Bobot } \\
\text { Skor }\end{array}$ \\
\hline \multicolumn{2}{|l|}{ The frequency of conducting audit 31} & 10 & 3 & 1 & 6 & \multirow{2}{*}{216} \\
\hline without complete audit procedure & $59,62 \%$ & $21,15 \%$ & $5,77 \%$ & $1,92 \%$ & $11,54 \%$ & \\
\hline \multicolumn{2}{|c|}{ The frequency of not using internal 21} & 12 & 11 & 5 & 3 & \multirow[t]{2}{*}{199} \\
\hline control procedure in audit & $40,38 \%$ & $23,08 \%$ & $21,15 \%$ & $9,62 \%$ & $5,77 \%$ & \\
\hline \multirow{2}{*}{$\begin{array}{l}\text { The frequency of ignoring the } \\
\text { consideration of internal audit in state } \\
\text { owned companies in an audit }\end{array}$} & 19 & 13 & 6 & 10 & 4 & \\
\hline & $36,54 \%$ & $25 \%$ & $11,54 \%$ & $19,23 \%$ & $7,69 \%$ & 189 \\
\hline \multicolumn{2}{|c|}{$\begin{array}{l}\text { The frequency of not using assertive } 28 \\
\text { information in formulating the objective }\end{array}$} & 4 & 8 & 7 & 5 & \\
\hline \multirow{2}{*}{\multicolumn{2}{|c|}{$\begin{array}{l}\text { of an audit and in substantive testing } 53,85 \% \\
\text { The frequency of not using analytical } 20 \\
\text { procedure in planning and final review of }\end{array}$}} & $7,69 \%$ & $15,38 \%$ & $13,46 \%$ & $9,62 \%$ & 199 \\
\hline & & 17 & 7 & 4 & 4 & \\
\hline & $32,69 \%$ & $13,46 \%$ & $7,69 \%$ & $7,69 \%$ & 201 \\
\hline \multirow{2}{*}{$\begin{array}{l}\text { The frequency of not conducting } \\
\text { confirmation in audit }\end{array}$} & 27 & 12 & 3 & 6 & 4 & \\
\hline & $51,92 \%$ & $23,08 \%$ & $5,77 \%$ & $11,54 \%$ & $7,69 \%$ & 208 \\
\hline \multirow{2}{*}{$\begin{array}{l}\text { The frequency of not using management } \\
\text { representation in audit }\end{array}$} & 17 & 17 & 10 & 3 & 5 & \\
\hline & $32,69 \%$ & $32,69 \%$ & $19,23 \%$ & $5,77 \%$ & $9,62 \%$ & 194 \\
\hline \multirow{2}{*}{$\begin{array}{l}\text { The frequency of not implementing the } \\
\text { obedience test toward the audit of client's } \\
\text { transactions }\end{array}$} & 25 & 7 & 7 & 10 & 3 & \\
\hline & $48,08 \%$ & $13,46 \%$ & $13,46 \%$ & $19,23 \%$ & $5,77 \%$ & 197 \\
\hline \multirow{2}{*}{$\begin{array}{l}\text { The frequency of reducing the sample size } \\
\text { than originally planned in an audit }\end{array}$} & 21 & 19 & 6 & 3 & 3 & \\
\hline & $40,38 \%$ & $36,54 \%$ & $11,54 \%$ & $5,77 \%$ & $5,77 \%$ & 208 \\
\hline \\
\hline calculation the cash flow or cash in hand & $59,62 \%$ & $21,15 \%$ & $9,62 \%$ & $7,69 \%$ & $1,92 \%$ & 223 \\
\hline \multicolumn{7}{|c|}{$\begin{array}{l}\text { The frequency of not conducting } \\
\text { complete auditing procedure when }\end{array}$} \\
\hline
\end{tabular}


Monoarfa and Dama: The Influence of Time Budget Pressure and Dysfunctional...

\begin{tabular}{lllllll}
\hline & $42,31 \%$ & $36,54 \%$ & $7,69 \%$ & $9,62 \%$ & $3,85 \%$ & \\
Accumulation & 262 & 142 & 70 & 58 & 40 & \\
& $45,80 \%$ & $24,83 \%$ & $12,24 \%$ & $10,14 \%$ & $6,99 \%$ & 2244 \\
\hline
\end{tabular}

Source: processed research data

Table 2 above shows that basically premature sign-off is one dimension of dysfunctional behavior which was almost never happen when auditors conduct their job. However, $17.13 \%$ of the respondents in this study admitted that they often and almost always commit this behavior. The indicator that contribute the most to this behavior out of the 12 indicators for this behavior is the frequency of the auditors ignore the consideration of the internal auditor in an audit by $26.92 \%$, the frequency when they do not use assertive information in formulating the objective of the audit and designing the substantive testing of the audit by $23.08 \%$ and when they do not conduct testing toward the obedience testing toward the audit of the client's transaction by $25 \%$.

\section{a) Under Reporting of Chargeable Time}

Dysfunctional behavior for underreporting of chargeable time admitted by the auditors in this study is moderately happen. This is evident from the accumulation of proportion of respondents who gave score 5 was $24.23 \%$, whereas those who give score 4 was $19.62 \%$.

Table 3. Summary of score on underreporting of chargeable time indicators

\begin{tabular}{|c|c|c|c|c|c|c|}
\hline $\begin{array}{c}\text { Under Reporting of Chargeable Time } \\
\text { indicator }\end{array}$ & Score $\mathbf{- 5}$ & Score -4 & Score -3 & \multicolumn{2}{|c|}{ Score -2Score -1} & \multirow[t]{2}{*}{$\begin{array}{l}\text { Total } \\
\text { score }\end{array}$} \\
\hline The frequency of committing & 15 & 7 & 12 & 11 & 7 & \\
\hline underreporting of chargeable time & $28,85 \%$ & $13,462 \%$ & $23,08 \%$ & $21,15 \%$ & $13,46 \%$ & 168 \\
\hline Frequency of working harder but & 10 & 12 & 16 & 6 & 8 & \\
\hline below the actual & $19,23 \%$ & $23,08 \%$ & $30,77 \%$ & $11,54 \%$ & $15,39 \%$ & 166 \\
\hline The frequency of asking and obtaining & 13 & 5 & 20 & 3 & 11 & \\
\hline increase of budget time and cost & $25 \%$ & $9,62 \%$ & $38,46 \%$ & $5,77 \%$ & $21,15 \%$ & 162 \\
\hline The frequency of dividing time into the & 9 & 13 & 10 & 11 & 9 & \\
\hline accomplish the audit & $17,31 \%$ & $25 \%$ & $19,23 \%$ & $21,15 \%$ & $17,31 \%$ & 158 \\
\hline $\begin{array}{l}\text { The frequency of allocating time to } \\
\text { different clients }\end{array}$ & 16 & 14 & 11 & 7 & 4 & 187 \\
\hline & $30,77 \%$ & $26,92 \%$ & $21,15 \%$ & $13,46 \%$ & $7,69 \%$ & \\
\hline$\Delta c c y$ & 63 & 51 & 69 & 38 & 39 & \\
\hline Accumulation & $24,23 \%$ & $19,62 \%$ & $26,54 \%$ & $14,62 \%$ & $15 \%$ & 841 \\
\hline
\end{tabular}

Source: processed research data

Table 3 above shows that $41.31 \%$ of the respondents often and almost always commit underreporting of chargeable time. Whereas, the possibility for the auditors to commit underreporting of chargeable time is shown by the frequency of the auditors to work harder by $42.31 \%$, and the frequency for the auditors to ask for additional budget time and cost was $34.62 \%$, the frequency of allocating time to the time that supposed to be used to accomplish the audit work is was $42.31 \%$ and the frequency to divide time into different client was $57.69 \%$. 


\section{3) Audit quality}

The audit quality is admitted by the auditors as respondents in this study as moderately good. This was evident on the proportion of the respondents who provided the response with score 5 was $22.12 \%$, whereas those who gave score 4 was $32.6 \%$. nevertheless, $21 \%$ of the respondents admitted that they were rarely and never able to produce expected audit quality. Meanwhile, the largest contribution of the instrument that can threaten the audit quality which rarely or never implemented is the frequency of accepting input and feedback needed by the client by $46.16 \%$, the frequency of active involvement of the leader in field audit by $38.46 \%$ and the frequency of act appropriately in audit implementation according to the audit program was by $57.69 \%$.

Table 4. Summary of the score on the audit quality indicator

\begin{tabular}{|c|c|c|c|c|c|c|}
\hline \multirow{3}{*}{$\begin{array}{l}\text { Audit quality indicator } \\
\text { The frequency of implementing experience } \\
\text { in audit implementation }\end{array}$} & \multirow{2}{*}{$\frac{\text { Score-5 }}{23}$} & \multirow{2}{*}{$\frac{\text { Score }-4}{17}$} & \multirow{2}{*}{$\frac{\text { Score }-\mathbf{3}}{10}$} & \multicolumn{2}{|c|}{ Score -2 Score -1 } & $\begin{array}{l}\text { Tota } \\
\text { score }\end{array}$ \\
\hline & & & & 2 & - & 217 \\
\hline & $44,23 \%$ & $32,69 \%$ & $19,23 \%$ & $3,85 \%$ & - & \\
\hline \multirow{2}{*}{$\begin{array}{l}\text { The frequency of having the effective skills } \\
\text { on client }\end{array}$} & 10 & 15 & 9 & 18 & - & 173 \\
\hline & $19,23 \%$ & $28,85 \%$ & $17,31 \%$ & $34,62 \%$ & - & \\
\hline \multirow{2}{*}{$\begin{array}{l}\text { The frequency of willingness to accept input } \\
\text { and feedback that suitable with the client } \\
\text { needs }\end{array}$} & 3 & 13 & 12 & 22 & 2 & \\
\hline & $5,77 \%$ & $25 \%$ & $23,08 \%$ & $42,31 \%$ & $3,85 \%$ & 149 \\
\hline \multirow{2}{*}{$\begin{array}{l}\text { The frequency of technical competencies in } \\
\text { implementation of standard audit }\end{array}$} & 13 & 26 & 13 & - & - & \\
\hline & $25 \%$ & $50 \%$ & $25 \%$ & - & - & 208 \\
\hline \multirow{2}{*}{$\begin{array}{l}\text { The frequency of being independent toward } \\
\text { the client }\end{array}$} & 35 & 13 & 1 & 3 & - & \\
\hline & $67,31 \%$ & $25 \%$ & $1,92 \%$ & $5,77 \%$ & - & 236 \\
\hline \multirow{2}{*}{$\begin{array}{l}\text { The frequency of self-training and due audit } \\
\text { care in audit }\end{array}$} & 7 & 28 & 17 & - & - & \\
\hline & $13,46 \%$ & $53,85 \%$ & $32,69 \%$ & - & - & 198 \\
\hline \multirow{2}{*}{$\begin{array}{l}\text { The frequency of strong commitment toward } \\
\text { the quality of the produced audit }\end{array}$} & 11 & 27 & 14 & - & - & \\
\hline & $21,15 \%$ & $51,92 \%$ & $26,92 \%$ & - & - & 205 \\
\hline \multirow{2}{*}{$\begin{array}{l}\text { The frequency of the active involvement of } \\
\text { the leader in field audit }\end{array}$} & 3 & 11 & 18 & 9 & 11 & \\
\hline & $5,77 \%$ & $21,15 \%$ & $34,62 \%$ & $17,31 \%$ & $21,15 \%$ & 142 \\
\hline \multirow{2}{*}{$\begin{array}{l}\text { The frequency of acting appropriately in } \\
\text { implementation of audit according to the } \\
\text { audit program }\end{array}$} & 1 & 7 & 14 & 13 & 17 & \\
\hline & $1,92 \%$ & $13,46 \%$ & $26,92 \%$ & $25 \%$ & $32,69 \%$ & 118 \\
\hline \multirow{2}{*}{$\begin{array}{l}\text { The frequency of being in contact with the } \\
\text { audit committee effectively }\end{array}$} & 1 & 10 & 27 & 14 & - & \\
\hline & $1,92 \%$ & $19,23 \%$ & $51,92 \%$ & $26,92 \%$ & - & 154 \\
\hline \multirow{2}{*}{$\begin{array}{l}\text { The frequency of having high ethical } \\
\text { standard and having knowledge on } \\
\text { accounting and auditing }\end{array}$} & 19 & 27 & 2 & 4 & - & \\
\hline & $36,54 \%$ & $51,92 \%$ & $3,85 \%$ & $7,69 \%$ & - & 217 \\
\hline \multirow{2}{*}{$\begin{array}{l}\text { The frequency of maintaining skeptical } \\
\text { attitude during implementation of audit }\end{array}$} & 12 & 10 & 14 & 13 & 3 & \\
\hline & $23,08 \%$ & $19,23 \%$ & $26,92 \%$ & $25 \%$ & $5,77 \%$ & 171 \\
\hline \multirow{2}{*}{ Accumulation } & 138 & 204 & 151 & 98 & 33 & \\
\hline & $22,12 \%$ & $32,69 \%$ & $24,20 \%$ & $15,71 \%$ & $5,29 \%$ & 2188 \\
\hline
\end{tabular}

Source: processed research data

Discussion. Through correlational matrix calculation, it was obtained that there is a strong negative correlation between time budget pressure (X1) and the quality of audit (Y) by 0.6382 . This means that each increase in time budget pressure will be followed by the reduction of audit quality, while positive medium correlation between time budget pressure (X1) and dysfunctional behavior by 0.4737 which means that each increase in 
time budget pressure will be followed by the increase of dysfunctional behavior. In detail, correlations among variables are presented in Table 5 below:

Table 5. The result of correlational analysis among variables

\begin{tabular}{llll}
\hline Correlation & Positive/negative & Extent of correlation & Degree of correlation \\
\hline $\mathrm{X}_{1}$ and $\mathrm{Y}$ & Negative & 0,6382 & Strong \\
$\mathrm{X}_{2}$ and $\mathrm{Y}$ & Negative & 0,6567 & Strong \\
$\mathrm{X}_{1}$ and $\mathrm{X}_{2}$ & Positive & 0,4737 & Moderate \\
\hline
\end{tabular}

Source: processed research data

Through invers matrix calculation, the pathway coefficient for independent variable (Xi) and dependent Variable (Y) showed that the time budget pressure correlation with quality audit $\mathrm{Y}$ is -0.42173 . This negative value showed negative influence between time budget pressure (X1) toward quality of audit (Y) which can be interpreted as the increase of time budget pressure (X1) will decrease quality of audit (Y). Meanwhile, the pathway coefficient or the estent of X2 (dysfunctional behavior)'s influence on Y (audit quality) is -0.45689 . This negative value can be interpreted that the increase of dysfunctional behavor (X2) can decrease the audit quality.

Further, the influence of external variables on the quality of audit is shown by the determinant coefficient of external variable which value is 0.4308 . in detail, the extent of influence of each variable is presented in the following table:

Table 6. Pathway coefficient result on the extent of each independent variable influence (X1 and X2) toward dependent variable (Y)

\begin{tabular}{lll}
\hline Pathway coefficient & & \\
\hline Pathway coefficient of $\mathrm{X}_{1}$ Toward Y & $\mathrm{Pyx}_{1}$ & $-0,42173$ \\
Pathway coefficient of $\mathrm{X}_{2}$ Toward Y & $\mathrm{Pyx}_{2}$ & $-0,45689$ \\
Multiple determinant coefficient & $\mathrm{R}^{2} \mathrm{y}\left(\mathrm{X}_{1}, \mathrm{X}_{2}\right)$, & 0,5692 \\
Pathway coefficient of external variable toward Y & $\mathrm{Py \varepsilon}$ & 0,6564 \\
Determinant coefficient of external variable toward Y & $\mathrm{P}^{2} \mathrm{y} \varepsilon$ & 0,4308 \\
\hline
\end{tabular}

\section{Source: processed research data}

Notes: $\mathrm{X}_{1}=$ Time Budget Pressure; $\mathrm{X}_{2}=$ dysfunctional behavior; $\mathrm{Y}=$ audit quality

Based on the calculation above, it pathway diagram can be described with the following figure:

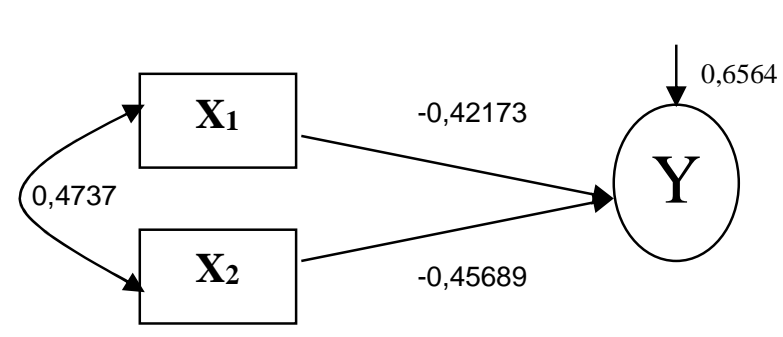

Figure 1. Result of Pathway coefficient value 
Based on the calculation above, it is found that there is an influence of time budget pressure on quality of audit. This result supports studies conducted by Coram (2001) and Soobaroyen and Chengabroyan (2005) which stated that time budget pressure influences the decrease of audit quality. Then, similar findings by Braun (2000) which found that high level time budget pressure has caused auditor paid less attention and less understood the investigation and potential indicators on financial statement misappropriation. In contrast with the findings in this study is the research by Sososutiksno (2003) who studied auditors on financial auditors agency (BPK) and financial and development auditing agency (BPKP) and found that time budget pressure has positive correlation with the quality of the audit. I suspected that this difference is due to the different characteristics between auditors who become respondents in these researches, in which auditors in BPK and BPKP are more qualified and have adequate experiences and knowledge as ideal auditors than auditors in BAWASDA. Thus, the impact of time budget pressure toward the quality of the audit may be influenced by the professionalism of the auditors. I also suspect that it is possible that budget allocation as guideline for time budget allocation in supporting the auditor operational in BPK and BPKP are more realistic than in BAWASDA, hence, pressure due to time budget will be different. The unrealistic budget allocation especially time budget will cause pressure on auditors in conducting audit.

\section{CONCLUSION}

The findings and discussion in this study have reached the following conclusion:

1. It shows that simultaneously it is proven that time budget pressure and dysfunctional behavior influence audit quality. Whereas the direction of the influence is shown by the pathway coefficient of variable $\mathrm{X}$ to Variable $\mathrm{Y}$ is negative influence. This means, the higher the time budget pressure with constant dysfunctional behavior the more reduced the audit quality.

2. It is also found, that partially, time budget pressure influence the quality of audit. The pathway coefficient shows that the direction of the influence of X1 variable toward $Y$ variable is negative. This means that the higher the time budget pressure, the lower the quality of the audit.

3. This study also reveals that partially the dysfunctional behavior influence the quality of audit. The pathway coefficient shows that the direction of the influence of X2 variable toward $\mathrm{Y}$ variable is negative. This means that the higher the dysfunctional behavior the lower the quality of the audit.

\section{Recommendation}

1. Considering the descriptive findings of this study and its analysis which showed that time budget pressure is strongly related with dysfunctional behaviors and will give negative influence on the quality of audit, it is recommended that the specific attention is paid to the budget in BAWASDA to make it more realistic with the audit purposes. BAWASDA needs to build internal communication and external communication especially with the house of representative. Hence, their budget allocation will be more realistic and less time budget pressure for the auditors in BAWASDA, thus, the quality of audit produced by BAWASDA will meet the expectation. 
2. The findings and analysis of this study shows that dysfunctional behaviors are found in all auditors in BAWASDA. These behaviors should be minimized or eradicated through more intensive supervision, trainings, and on-going assistance toward auditors in their auditing process. These efforts are expected to make auditors understand and increase their awareness on the importance of audit procedures to find evidence and reporting misappropriation, thus, premature sign off can be avoided. Further, through these efforts auditors are expected to become more honest in reporting their chargeable time (not conducting underreporting of chargeable time and become discipline toward time budget allocated to avoid inappropriate planning of time budget in the future.

\section{REFERENCES}

Arens, Alvin \& James K. Loebecke. (2005). Auditing. Prentice-Hall, Inc. A Simon \& Schuster company.. Englewood Clift, New Jersey

Azad, Ali N., (1994). "Time Budget Pressure and Filtering of Time Practices in Internal Auditing: A survey", Managerial Auditing Journal. 9 (6), 17-25

State Audit Agency - Republic of Indonesia, (1995). "Government standard of audit"

Behn, Bruce K et al., (1997). "The Determinants of Audit Client Satisfaction Among Clients of Big 6 Firms", Accounting Horizons, 11 (1), 7-24

Braun, Robert L., (2000). "The Effect of Time Pressure on Auditor Attention to Qualitative Aspects of Misstatements Indicative of Potential Financial Financial Reporting". Accounting, Organizations and Society, 25, 243-259

Broberg, Pernilla; Tagesson, Torbjorrn; Argento, Daniela; Gyllengahm, Niclas and Martensson, Ola, (2017). "Explaining the quality audit quality budget audit in Sweden", Journal of Management and Governance, 21, 313-350.

Carcello, Joseph V, (1992). Audit Quality Attributes: "The Perceptions of Audit Partners, Preparers, and Financial Statements Users", Auditing: A Journal of Practice \& Theory, 11 (1), 90-104

Cook, Ellen and Timothy Kelley, (1988). "Management of An Accouting Practice", The CPA Journal, 58 (7), 83-86 , (1991). "An International Comparison of Audit Time Budget Pressure: The United States and New Zealand", The Woman CPA, 53 (2), 25-30

Coram, Paul, Juliana Ng., And David R Woodliff, (2004). "The Effect of Risk of Misstatement on the Propensity to Commit Reduced Audit Quality Acts under Time Budget Pressure", Auditing: A Journal of Practice \& Theory, 23 (2), 159-167

(2001). "The Effect of Time Budget Pressure and Risk of Error on Performance Auditors", Working Paper, The University of Western Australia.

Christina Sososutiksno, (2003). "The Correlation of Time Budget Pressure and Dysfunctional Behavior and Its Effect on the Quality of Audit / the correlation of time budget pressure and dysfunctional behavior and its influence toward audit quality, Yogyakarta: Thesis not published

Davis, Keith, and John J. Newstrom, (1995). "Human Behavior at Work: Organizational Behavior". Mc Graw Hill

DeAngelo, Linda Elizabeth, (1981, "Auditor Size and Audit Quality", Journal of Accounting and Economics, 3: 183-199

DeZoort, F. Todd, (1998). "Time Pressure Research in Auditing: Implications for Practice", The Auditor's Report, 22 (1), 11-14 
and Alan T.Lord, (1997). "A Review and Synthesis of Pressure Effects Research in Accounting", Journal of Accounting Literature. 16, 28-85

Djamaludin Ancok, (1995). "Technique of developing measurement scale", Gajah Mada University Yogyakarta

Donnelly, David P., Jeffrey J. Quirin and David O'Bryan, (2003). Auditors of Acceptance of Functional Audit Behavior: An Explanatory Model Using Auditors' Personal Characteristics, Behavioral Research In Accounting, Vol. 15, Printed in USA, pp. $87-110$

Gibson, James L., John M. Ivancevich and James H. Donnethe lly Jr., (1999). Organizations: Behavior, Structure, Processess, Richard D Irwin Inc, USA.

Glover, Steven M., (1997). "The Influence of Time Pressure and Accountability on Auditors' Proces of Nondeagnostic Information ", Journal of Accounting Research, 32 (2), 213-225

Gordon, Judith R., (1999). "Organizational Behavior: A Diagnostic Approach", Prentice Hall International Inc., New Jersey.

Govindarajan, V., (1994). "Appropriateness of Accounting Data in Performance Evaluation of Environmental Uncertainty and Intervening Variables", Accounting Organizations and Society, 2: 496-516

Harun Al Rasyid, (1994). The Basics of Applied Statistics / basic of applied statistics. unpublished. Postgraduate program UNPAD, Bandung.

Husein Umar, (2003). Method of applied accounting research/research method of applied accounting, Ghalia Indonesia, Jakarta.

Indonesian Institute of Accountants. (2001). Professional Standards of Public Accountants / professional standards of public accounting. 2nd printing. Yogyakarta: YPKN.

If, Ali Amin, (2013). “The Influence Of Competence, Independence And Professional Skepticism In Internal To Audit Quality Auditors (Survey Perception Inspector Local Government Auditors in Ambon City)", Journal of Economics, Cita Ekonomika, VII (2).

Kaplan, Steven E., (1995). "An Examination of Auditors' Reporting Intentions Upon Discovery of Procedures Prematurely Signed-off", Auditing: A Journal of Practice \& Theory, 14 (2), 90-104

Kelley, Timothy, Loren Margheim and Diane Pattison, (1999). "Survey, on The Differential Effects of Time-Limit Pressure Versus Time Budget Pressure on Auditor Behavior", The Journal of Applied Business Research. 15 (4), 117-128

Kelley, T. and R.E. Seiler, (1982). "Stress and Time Budget Auditor", The CPA Journal, December, pp. 24-34 